\title{
ECONOMICA
}

Journal of Economic and Economic Education Vol.3 No.2 (207 - 218)

\section{PENGARUH KOMITMEN KERJA DAN MOTIVASI KERJA TERHADAP DISIPLIN KERJA GURU BIDANG STUDI IPS SMAN KABUPATEN PADANGPARIAMAN}

\author{
Rika Verawati \\ Dosen Program Studi Pendidikan Ekonomi STKIP- PGRI Sumbar \\ Jl. Gunung Pangilun No.1, Padang Sumatera Barat \\ Email: zahira_unp@yahoo.com \\ submited: 2015.01.26 reviewed:2015.02.28 accepted: 2015.04.26 \\ http://dx.doi.org/10.22202/economica.2015.v3.i2.257
}

\begin{abstract}
This article intended to reveals the extent of (1) the influence of work commitment toward work motivation of IPS teachers at SMAN Padang Pariman regency. (2) It is also aimed to analyze the influence of work commitment and work motivation toward the discipline of IPS teachers at SMAN Padang Pariaman regency. This research is quantitative research that consists of two independent variables and one dependent variable. The population of this research was 132 of IPS teachers. In taking the sample, the researcher used proportional stratified random sampling, and was selected 99 teachers as the sample of this research. The researcher distributed the questionnaire to collect the data, and analyze the data by using the path way analysis and hypothesis testing by using $t$ test and $F$ test at the level of significant 0,05 by using SPSS program version 17.
\end{abstract}

\begin{abstract}
Abstrak
Artikel ini dimaksudkan untuk mengungkapkan sejauh mana (1) pengaruh komitmen kerja terhadap motivasi kerja guru IPS di SMAN Kabupaten Padang Pariman. (2) Hal ini juga bertujuan untuk menganalisis pengaruh komitmen kerja dan motivasi kerja terhadap disiplin guru IPS di SMAN Kabupaten Padang Pariaman. Penelitian ini merupakan penelitian kuantitatif yang terdiri dari dua variabel independen dan satu variabel dependen. Populasi penelitian ini adalah 132 guru IPS. Dalam mengambil sampel, peneliti menggunakan proporsional stratified random sampling, dan terpilih 99 guru sebagai sampel penelitian ini. Peneliti menyebarkan kuesioner untuk mengumpulkan data, dan menganalisa data dengan menggunakan analisis jalur jalan dan pengujian hipotesis dengan menggunakan uji t dan uji F pada tingkat signifikan 0,05 dengan menggunakan program SPSS versi 17.
\end{abstract}

Keywords: work commitment, work motivation, discipline 


\section{PENDAHULUAN}

Dalam Undang-undang No. 20 Tahun 2003 tentang Sistem Pendidikan Nasional dijelaskan bahwa pendidikan adalah usaha sadar dan terencana untuk mewujudkan suasana belajar dan proses pembelajaran agar peserta didik secara aktif mengembangkan potensi dirinya untuk memiliki kekuatan spiritual keagamaan, pengendalian diri, kepribadian, kecerdasan, akhlak mulia, serta keterampilan yang diperlukan dirinya, masyarakat, bangsa dan negara. Pendidikan nasional berfungsi mengembangkan kemampuan dan membentuk watak serta peradaban bangsa yang bermartabat.

Pendidikan pada hakekatnya adalah usaha membudayakan manusia atau memanusiakan manusia, pendidikan amat strategis untuk mencerdaskan kehidupan bangsa dan diperlukan guna meningkatkan mutu bangsa secara menyeluruh. Peningkatan mutu pendidikan ditentukan oleh kesiapan sumber daya manusia yang terlibat dalam proses pendidikan dalam hal ini guru. Guru merupakan merupakan elemen kunci dalam sistem pendidikan, khususnya disekolah. Begitu pentingnya peran guru dalam menstransformasi input-input pendidikan, sehingga disekolah tidak akan ada perubahan atau peningkatan tanpa adanya perubahan dan peningkatan kualitas dan disiplin kerja guru.

Seorang guru yang baik tidak akan bisa menegakkan disiplin kepada siswanya, jika dirinya tidak disiplin. Artinya, agar guru dapat menanamkan kesadaran dan nilai-nilai akan arti penting disiplin kepada siswa, terlebih dahulu guru harus membiasakan dirinya taat dan patuh kepada ketentuan dan peraturan yang berlaku.

Disiplin guru erat kaitannya dengan ketaatannya dalam melaksanakan tugas. Seorang guru dapat dikatakan mempunyai disiplin, jika ia memiliki kesadaran akan jam kerja dan punya komitmen terhadap pelaksanaan tugasnya. Seorang guru yang baik biasanya masuk kelas tepat pada waktunya, mengakhiri jam pelajaran sesuai dengan waktu yang ditentukan, dan banyak lain kegiatan-kegiatan atau perilaku-perilaku yang akan menunjukkan disiplin seorang guru. Hal ini sejalan dengan pendapat Tu'u (2004:31) menyebutkan istilah disiplin kerapkali terkait dan menyatu dengan istilah tata tertib dan ketertiban. Ketertiban mempunyai arti kepatuhan seseorang dalam mengikuti peraturan atau tata tertib karena didorong atau disebabkan oleh sesuatu yang datang dari luar dirinya.

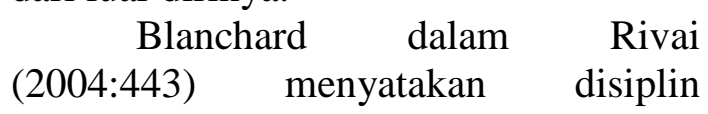
berhubungan erat dengan motivasi kerja seseorang, ia mengasumsikan bahwa jika organisasi ingin berhasil maka pimpinan harus membangun motivasi kerja pegawainya, karena dengan terbentuknya motivasi kerja pegawai yang baik maka upaya menegakkan disiplin kerja yang baik akan mudah diusahakan. Mangkunegara (200:129) mengatakan "Diciplin is management as action to en fore organitation standards". Disiplin kerja dapat diartikan sebagai pelaksanaan manajemen untuk memperteguh pedoman-pedoman organisasi. Sastrohadiwiryo (2005:291) mendefenisikan disiplin sebagai suatu sikap menghormati, menghargai, patuh dan taat terhadap peraturan yang berlaku, baik yang tertulis serta sanggup menjalankannya dan tidak mengelak untuk menerima sangsi-sangsinya apabila ia melanggar tugas dan wewenang yang diberikan kepadanya.

Rivai (2004:445) menyatakan bahwa disiplin kerja guru dipengaruhi oleh berbagai faktor, baik faktor internal 
maupun eksternal. Faktor internal yaitu faktor yang dihubungkan dengan sifatsifat seseorang, seperti motivasi kerja, semangat kerja dan inisiatif kerja. Disiplin kerja pada dasarnya merupakan gabungan dari kata disiplin yang dikaitkan dengan tugas seorang individu dalam pekerjaannya.

Berdasarkan tabel 1 hasil pengamatan dan studi pendahuluan yang penulis lakukan terhadap 12 orang guru bidang studi IPS di SMAN 1 Batang Anai dan 5 orang guru bidang studi IPS SMAN Kayu Tanam, diketahui bahwa guru bidang studi IPS belum memperlihatkan disiplin kerja yang begitu baik sebagaimana diharapkan yakni dengan indikasi yang diperlihatkan oleh data tabel sebagai berikut:

Tabel 1. Hasil Studi Pendahuluan Disiplin Kerja Guru (Y)

\begin{tabular}{|c|c|c|c|}
\hline No & Pernyataan & $\begin{array}{l}\text { Jumlah } \\
\text { (orang) }\end{array}$ & Rata-rata \\
\hline \multicolumn{4}{|c|}{ SMAN 1 Batang Anai } \\
\hline 1 & $\begin{array}{l}\text { Guru tidak mempersiapkan RPP } \\
\text { sebelum mengajar }\end{array}$ & 4 & 2,50 \\
\hline 2 & $\begin{array}{l}\text { Guru sering datang terlambat } \\
\text { kesekolah }\end{array}$ & 3 & 3,00 \\
\hline 3 & $\begin{array}{l}\text { Kurangnya menghargai waktu } \\
\text { dalam mengajar }\end{array}$ & 3 & 2,00 \\
\hline \multicolumn{4}{|c|}{ SMAN 1 Kayu Tanam } \\
\hline 1 & $\begin{array}{l}\text { Guru Tidak mempersiapkan RPP } \\
\text { sebelum mengajar }\end{array}$ & 2 & 3,00 \\
\hline 2 & $\begin{array}{l}\text { Guru kurang konsisten dalam } \\
\text { melaksanakan tugas mengajar }\end{array}$ & 2 & 2,00 \\
\hline 3 & $\begin{array}{l}\text { Guru tidak memiliki target dalam } \\
\text { mengajar }\end{array}$ & 1 & 2,00 \\
\hline
\end{tabular}

Sumber: Studi Pendahuluan 2013

Berdasarkan fenomena yang terlihat tersebut, penulis mengasumsikan bahwa rendahnya disiplin kerja guru bidang studi IPS SMAN Batang Anai dan Kayu Tanam disebabkan oleh banyak faktor diantaranya, komitmen kerja guru dan motivasi kerja guru dalam bekerja. Pengaruh faktor-faktor terhadap disiplin kerja menurut Neustrom dalam Nitisemitro (2000:90) menjelaskan bahwa tingkat disiplin kerja pegawai dipengaruhi oleh beberapa faktor seperti: 1) Tingkat komitmen kerja, 2) Adanya Pemberian imbalan yang adil, 3) Motivasi kerja, 5) Kepuasan kerja, 5)
Kepemimpinan. Disiplin kerja yang baik sangat bergantung kepada dukungan dari komitmen kerja dan motivasi kerja agar semua pekerjaan dapat dilakukan dengan baik. Komitmen merupakan faktor yang paling dominan berpengaruh terhadap disiplin kerja guru. Akan tetapi, dari hasil pengamatan dan studi pendahuluan yang penulis lakukan terhadap 12 orang guru Bidang studi IPS SMAN dan 5 orang guru bidang studi IPS SMAN Kayu Tanam terlihat bahwa komitmen kerja guru masih relatif rendah. Indikasi yang diperlihatkan oleh data tabel sebagai berikut: 
Tabel 2. Hasil Studi Pendahuluan Komitmen Kerja Guru (X1)

\begin{tabular}{|c|c|c|c|}
\hline No & Pernyataan & $\begin{array}{l}\text { Jumlah } \\
\text { (orang) }\end{array}$ & Rata-rata \\
\hline \multicolumn{4}{|c|}{ SMAN 1 Batang Anai } \\
\hline 1 & $\begin{array}{l}\text { Guru sekedar memenuhi kewajiban } \\
\text { memberikan materi dikelas }\end{array}$ & 4 & 2,75 \\
\hline 2 & $\begin{array}{l}\text { Guru hanya memenuhi terget kehadiran } \\
\text { datang kesekolah }\end{array}$ & 2 & 1,50 \\
\hline 3 & $\begin{array}{l}\text { Guru kurang memberikan ide-ide dalam } \\
\text { kemajuan pendidikan }\end{array}$ & 3 & 2,67 \\
\hline \multicolumn{4}{|c|}{ SMAN 1 Kayu Tanam } \\
\hline 1 & $\begin{array}{l}\text { Guru kurang aktif mencari ide-ide baru } \\
\text { untuk pembelajaran }\end{array}$ & 3 & 2,33 \\
\hline 2 & $\begin{array}{l}\text { Guru tidak aktif memberikan masukan } \\
\text { dalam rapat }\end{array}$ & 1 & 3,00 \\
\hline 3 & $\begin{array}{l}\text { Guru jarang hadir dalam kegiatan yang } \\
\text { diadakan sekolah }\end{array}$ & 1 & 2,00 \\
\hline
\end{tabular}

Sumber: Studi Pendahuluan 2013

Data tabel 2 di atas, terlihat bahwa masih rendahnya komitmen kerja guru bidang studi IPS SMAN 1 Batang Anai dan guru bidang studi IPS SMAN guru bidang studi IPS SMAN Kayu Tanam, bahwa guru dalam melaksanakan tugas seolah-olah hanya sekedar memenuhi kewajibannya untuk memberikan materi pada jam mengajar. Kehadiran guru hanya untuk memenuhi tugas jam mengajar yang diberikan itu. Dengan kata lain, guru hanya memenuhi target kehadiran di sekolah tersebut.

Fenomena yang memperlihatkan rendahnya komitmen kerja guru dalam mengajar adalah guru kurang persiapan dalam mengajar, hal ini terlihat dari kehadiran guru yang datang terlambat ke sekolah, bahkan setelah datang di sekolah masih mengundur-undur waktu untuk masuk ke dalam kelas. Sebagian guru masuk ke dalam kelas tidak membawa perangkat kegiatan belajar mengajar yang akan memandu guru dalam proses belajar mengajar. Selain itu juga kurangnya masukan dan pemikiran serta ide-ide dari guru dalam rangka peningkatan dan kemajuan pendidikan di sekolah tersebut

Hal ini bertolak belakang dengan pengertian komitmen menurut Robbins (2006: 170) komitmen didefenisikan sebagai suatu keadaan dimana seorang pegawai memihak kepada organisasinya dan tujuan-tujuannya dan berniat tetap menjadi anggota menurut organisasi tersebut. Menurut Sehartian (2007:44) komitmen kerja merupakan kecenderungan dalam diri seseorang untuk merasa aktif dengan penuh rasa tanggung jawab.

Kartono (2008:76) memberikan defenisi komitmen kerja sebagai janji tanggung jawab dan keterikatan, dimana keputusan yang diambil berdasarkan sikap-sikap dan perjanjian yang dianut pada saat itu dan cenderung mengkristalisasikan sikap-sikap. Nawawi (2005:160) menjelaskan keteguhan hati untuk melakukan suatu pekerjaan dianggap dan diyakini suatu komitmen kerja.

Menurut Rivai (2008:284) komitmen kerja pada organisasi adalah suatu keadaan dimana seorang karyawan memihak pada suatu organisasi tertentu dan tujuan-tujuannya serta memelihara keanggotaanya dalam organisasi.

Berdasarkan fenomena tersebut, maka penulis mengasumsikan bahwa rendahnya disiplin kerja guru bidang studi IPS SMAN 1 Batang Anai dan Kayu Tanam disebabkan oleh banyak faktor, diantaranya adalah komitmen kerja dan motivasi kerja. 
Motivasi merupakan faktor yang paling dominan berpengaruh terhadap disiplin kerja guru. Akan tetapi, dari hasil pengamatan dan studi pendahuluan yang penulis lakukan terhadap 12 orang guru bidang studi IPS di SMAN 1 Batang Anai dan 5 orang guru bidang studi IPS SMAN Kayu Tanam terlihat bahwa motivasi kerja guru masih relatif rendah dengan indikasi:

Tabel 3. Hasil Studi Pendahuluan Motivasi Kerja Guru (X2)

\begin{tabular}{|c|c|c|c|}
\hline \multirow{2}{*}{\multicolumn{4}{|c|}{$\begin{array}{l}\text { No } \quad \text { Pernyataan } \\
\text { SMAN } 1 \text { Batang Anai }\end{array}$}} \\
\hline & & & \\
\hline 1 & $\begin{array}{l}\text { Kurang memiliki tanggung } \\
\text { jawab melaksanakan tugas }\end{array}$ & 3 & 3,00 \\
\hline 2 & $\begin{array}{l}\text { Kurang memiliki target dan } \\
\text { tujuan yang jelas dalam } \\
\text { pembelajaran }\end{array}$ & 2 & 3,00 \\
\hline 3 & $\begin{array}{l}\text { Memiliki perasaan tidak } \\
\text { senang dalam bekerja }\end{array}$ & 3 & 1,33 \\
\hline \multicolumn{4}{|c|}{ SMAN 1 Kayu Tanam } \\
\hline 1 & $\begin{array}{l}\text { Guru kurang memiliki } \\
\text { tanggung jawab dalam tugas }\end{array}$ & 2 & 2,00 \\
\hline 2 & $\begin{array}{l}\text { Guru tidak mempersiapkan } \\
\text { diri sebelum melaksanakan } \\
\text { tugas }\end{array}$ & 2 & 2,50 \\
\hline 3 & $\begin{array}{l}\text { Cenderung menjalankan } \\
\text { tugas agar memperoleh } \\
\text { insentif }\end{array}$ & 1 & 3,00 \\
\hline
\end{tabular}

Sumber: Studi Pendahuluan 2013

Dari tabel 3 di atas terlihat bahwa masih rendahnya motivasi kerja guru bidang studi IPS SMAN 1 Batang Anai dan Kayu Tanam, terlihat bahwa sebagian guru kurang memiliki tanggung jawab dalam melaksanakan tugas mengajar. Dalam proses pembelajaran guru dituntut memiliki kreatifitas dan kematangan dalam mengajarkan materi, bukan dengan cara memberikan siswa tugas atau catatan untuk disalin sampai habis jam pelajaran tanpa diterangkan siswa itu menjadi pintar akan tetapi karena bimbingan dan penjelasan dari guru yang dibutuhkan siswa.

Fenomena lain yang terjadi pada guru bidang studi IPS SMAN Batang Anai dan Kayu Tanam adalah guru kurang memiliki target dan tujuan yang jelas dalam proses pembelajaran. Guru seolah-olah mengajar hanya memenuhi tuntutan mata pelajaran yang diberikan tanpa mengerti akan ilmu yang akan diberikan kepada siswa. Fenomena lain yang terlihat guru tidak memiliki prestasi untuk menjadi yang terbaik di antara teman-teman yang lain sehingga guru teladan dan yang kompeten dalam bidangnya tidak tampak. Dalam arti kata tidak ada guru yang unggul dalam bidang mengajarnya. Kemudian terlihat juga sebagian guru dalam melaksanakan tugas mengajar terkesan tidak senang dengan profesinya sebagai guru. Bahkan ada sebagian guru yang pagi- pagi sudah mengantuk dan tidur diruangan majelis guru dalam jadwal pelajarannya dan hanya meninggalkan catatan kepada siswa di kelas.

Hal di atas tidak sejalan dengan teori motivasi menurut Menurut Hamzah (2008:3) Istilah motivasi berasal dari kata motif yang dapat diartikan sebagai kekuatan dalam diri individu, yang menyebabkan individu tersebut bertindak atau berbuat.

Lantham (2004:485) menyatakan bahwa "Work motivation is a set of energietic forces that originate buth 
within as well as beyond an individual's being, to initiate work realated behaviour and to determine its form. Direction, intensity and duration". Motivasi kerja adalah suatu sikap mental yang dimiliki oleh seseorang yang berasal dari dalam dirinya dan didorong oleh lingkungan yang mendorongnya untuk melakukan suatu kegiatan atau aktifitas untuk mencapai tujuan pribadi dan perusahaan tempat ia bekerja.

Tisnawati dan Saefullah (2005:243) Motivation is the set of forces that cause people to behave in certain ways. Motivasi adalah sesuatu yang mendorong seseorang untuk menunjukkan perilaku tertentu.

Apabila fenomena yang terlihat dilapangan dibiarkan terus menerus tanpa adanya perubahan kearah yang lebih baik maka tujuan pendidikan tidak akan tercapai dan akan mengakibatkan kualitas lulusan yang rendah dan tidak memiliki kompetensi untuk bersaing. Oleh kerena itu, persoalan diatas harus disikapi oleh elemen terkait sehingga tujuan pendidikan dapat tercapai.

Penelitian ini bertujuan untuk: (1) Pengaruh komitmen kerja terhadap motivasi kerja guru bidang studi IPS SMAN Kabupaten Padang Pariaman. (2) Pengaruh komitmen kerja dan motivasi kerja guru terhadap disiplin kerja guru bidang studi IPS SMAN Kabupaten Padang Pariaman.

\section{METODE PENELITIAN}

Populasi dalam penelitian ini adalah seluruh guru bidang studi IPS SMAN Kabupaten Padang Pariaman. Jumlah populasi dalam penelitian ini adalah 132 orang guru dan taraf kepercayaan yang diinginkan 95\%, maka $\mathrm{d}=0,05 \%$. Rumus Taro Yamane:

$$
\begin{aligned}
& n=\frac{\mathrm{N}}{1+\mathrm{N} \cdot \mathrm{d}^{2}} \\
& n=\frac{132}{1+132(0,05)^{2}}=99,25
\end{aligned}
$$

Keterangan:

$\mathrm{n} \quad=$ Jumlah sampel

$\mathrm{N} \quad=$ Jumlah populasi

$d \quad=$ Presisi yang ditetapkan

Teknik penarikan sampel menurut tingkatan guru yang berada dilingkungan masing-masing sekolah secara (Stratified Porpotional Randon sampling) sehingga diperoleh 99 sampel. Analisis terhadap hasil penelitian yang dilakukan adalah melalui analisis jalur (Path Analysis) diolah dengan bantuan SPSS Vers.17 guna mengetahui besar pengaruh masingmasing variabel eksogen dan endogen dengan struktur jalur dibagi menjadi 2 struktur.

\section{PEMBAHASAN}

\section{Uji Persyaratan Analisis}

a. Uji Normalitas

Dalam hal ini pengujian normalitas dilakukan dengan menggunakan one Sample Kolmogorov Smirnov Test, dengan taraf signifikansi > 0,05. Hasil analisis dapat dilihat pada tabel berikut:

Tabel 4. Uji Normalitas

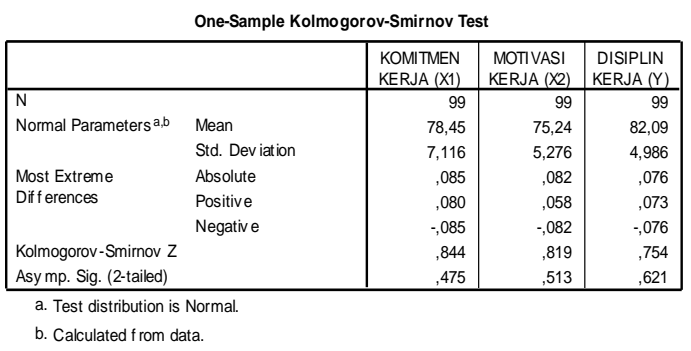

Dari Tabel 4 terlihat bahwa hasil normalitas menyatakan nilai Kolmogorov-Smirnov untuk masingmasing variabel $>0,05$. Hal ini dapat dilihat dari Asymp sig (2-tailed) variabel komitmen kerja (X1) 0,475>0,05, variabel motivasi kerja (X2) 0,513> 
0,05 dan variabel disiplin kerja (Y) $0,621>0,05$ dari hasil olahan data dinyatakan bahwa data yang digunakan dalam penelitian ini berdistribusi normal.

b. Uji Homogenitas

Analisis menggunakan Levene Statistik.

Tabel 5. Uji Homogenitas

\begin{tabular}{|c|c|c|c|c|}
\hline & $\begin{array}{c}\text { Levene } \\
\text { Statistik }\end{array}$ & df1 & df2 & Sig. \\
\hline Komitmen Kerja (X1) &, 757 & 14 & 84 &, 711 \\
Motivasi Kerja (X2) &, 932 & 14 & 84 &, 538 \\
Disiplin Kerja (X3) & 1,208 & 14 & 84 &, 258 \\
\hline
\end{tabular}

Sumber: Olahan Data Primer 2013

Dari Tabel 5 menunjukkan bahwa masing-masing variabel bebas maupun terikat memiliki nilai Signifikansi lebih besar dari $\alpha 0,05$, hal ini berarti data ketiga variabel homogen dan memenuhi syarat untuk analisis pengujian hipotesis.

\section{Analisis Jalur}

a. Substruktur 1 Pengaruh Komitmen Kerja Guru Terhadap Motivasi Kerja Guru.

Hasil analisis pengaruh variabel komitmen kerja terhadap motivasi kerja bidang studi IPS SMAN Kabupaten Padang Pariaman dapat dilihat pada tabel berikut:

Tabel 6. Pengaruh Komitmen Kerja Terhadap Motivasi Kerja Guru.

\begin{tabular}{cccc}
\hline Variabel & $\begin{array}{c}\text { Koefisien } \\
\text { Jalur }\end{array}$ & $\mathbf{t}_{\text {hitung }}$ & Sig. \\
\hline Komitmen & 0,490 & 5541 & 0.000
\end{tabular}

$\mathrm{R}^{2} \quad=0,240$

Fhitung $=30.704$

$\frac{\text { Sig } \quad=0.000}{\text { Sumber: Olahan Data Primer: } 2013}$

Berdasarkan hasil penelitian substruktur 1, menunjukkan bahwa komitmen kerja berdasarkan uji $\mathrm{F}$ berpengaruh signifikan terhadap motivasi kerja guru bidang studi IPS SMAN Kabupaten Padang Pariaman yaitu sebesar $F_{\text {hitung }}$ 30.704. Sedangkan pengaruh secara parsial koefisien jalur komitmen kerja signifikan terhadap motivasi kerja bidang studi IPS SMAN Kabupaten Padang Pariaman yaitu $\mathrm{t}_{\text {hitung }}$ $=5,541$ sehingga hipotesis yang diajukan diterima. Pengaruh lain terhadap motivasi kerja guru

$$
\begin{aligned}
P \times 2 & =\sqrt{1-R^{2} \times 1 \times 2} \\
& =\sqrt{1-0.240} \\
& =\sqrt{0.760} \\
& =0.872
\end{aligned}
$$

Perana faktor lain yang tidak diteliti terhadap disiplin kerja guru dalam penelitian ini adalah sebesar 0.872. Hasil pengujian substruktur 1 dapat dilihat pada gambar berikut:

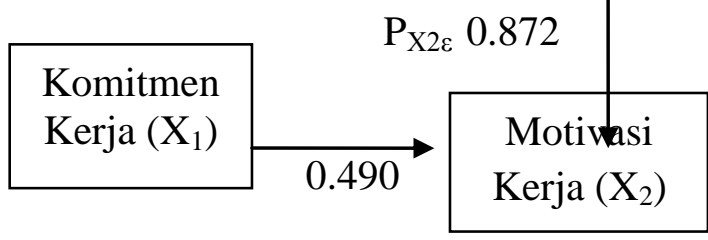

Gambar 1: Hasil Analisis Substruktur 1

\section{b. Substruktur 2 Pengaruh Komitmen Kerja dan Motivasi Kerja Terhadap Disiplin Kerja Guru.}

Hasil analisis pengaruh variabel komitmen kerja dan motivasi kerja terhadap disiplin kerja guru bidang studi IPS SMAN Kabupaten Padang Pariaman dapat dilihat pada tabel berikut:

Tabel 7. Pengaruh Komitmen Kerja dan Motivasi Kerja terhadap Disiplin Kerja Guru

\begin{tabular}{lccc}
\hline \multicolumn{1}{c}{ Variabel } & $\begin{array}{c}\text { Koefisien } \\
\text { Jalur }\end{array}$ & $\mathbf{t}_{\text {hitung }}$ & Sig. \\
\hline Komitmen & 0,314 & 3511 & 0.001 \\
Motivasi & 0,409 & 4578 & 0.000 \\
$\mathrm{R}^{2} \quad=0,377$ & & \\
Fhitung $=28.991$ & & \\
Sig $=0.000$ & & \\
\hline Sumber: Olahan Data Primer: & \\
\end{tabular}

Sumber: Olahan Data Primer: 2013 
Berdasarkan hasil penelitian analisis substruktur 2, menunjukkan bahwa komitmen dan motivasi kerja berpengaruh signifikan terhadap disiplin kerja guru bidang studi IPS SMAN Kabupaten Padang Pariaman, yaitu sebesar $=33.70 \%$. Sedangkan pengaruh secara parsial koefisien analisis jalur komitmen kerja berpengaruh signifikan terhadap motivasi kerja yakni sebesar $31.40 \%$, dan koefisien motivasi kerja berpengaruh signifikan terhadap disiplin kerja yakni sebesar $40.90 \%$, sehingga hipotesis diterima. Pengaruh lain terhadap disiplin kerja guru.

$$
\begin{aligned}
P y & =\sqrt{1-R^{2} \times 1 \times 2} \\
& =\sqrt{1-0.377} \\
& =\sqrt{0.623} \\
& =0.789
\end{aligned}
$$

Perana faktor lain yang tidak diteliti terhadap disiplin kerja guru dalam penelitian ini adalah sebesar 0.789. Hasil pengujian substruktur 2 dapat dilihat pada gambar berikut:

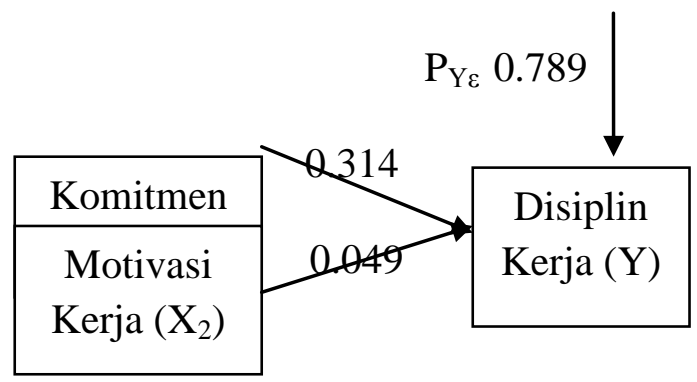

Gambar 2: Hasil Analisis Substruktur 2

\section{c. Pengujian Hipotesis}

1) Hipotesis 1

"Komitmen kerja guru berpengaruh signifikan terhadap motivasi kerja guru bidang studi IPS SMAN Kabupaten Padang Pariaman". Berdasarkan hasil analisis data yang diperoleh nilai $\mathrm{F}_{\text {hitung }}$ sebesar 30.704 dengan sig. $0.000<$ 0.005. Hal ini menunjukkan bahwa komitmen kerja memiliki pengaruh yang signifikan terhadap motivasi kerja guru bidang studi IPS SMAN Kabupaten
Padang Pariaman, sehingga hipotesis dalam penelitian ini diterima.

\section{2) Hipotesis 2}

"Komitmen kerja dan motivasi kerja guru berpengaruh signifikan terhadap disiplin kerja guru bidang studi IPS SMAN Kabupaten Padang Pariaman". Berdasarkan hasil analisis data yang diperoleh nilai $F_{\text {hitung }}$ sebesar 28.991 dengan sig. $0.000<0.005$. Hal ini menunjukkan bahwa komitmen kerja dan motivasi kerja guru memiliki pengaruh yang signifikan terhadap disiplin kerja guru bidang studi IPS SMAN Kabupaten Padang Pariaman, sehingga hipotesis dalam penelitian ini diterima.

Hasil olahan deskriptif data indikator dari disiplin kerja guru yang memiliki skor terendah adalah ketaatan dan kepatuhan. Hal tersebut dikarenakan sebagian besar responden kurang taat dan patuh dalam mematuhi peraturan baik secara tertulis maupun yang tidak tertulis, seperti kesediaan mematuhi secara sadar setiap peraturan yang berlaku dalam aturan sekolah. Seorang guru dapat dikatakan disiplin apabila mampu mencerminkan sikap hidup dan perilaku yang bertanggung jawab. Pendapat Tu'u (2004:31) mengenai disiplin guru yakni, kondisi yang tercipta dan terbentuk melalui proses dari serangkaian perilaku yang menunjukkan nilai-nilai ketaatan, kepatuhan, kesetiaan, keteraturan dan ketertiban. Nilai-nilai tersebut menjadi bagian perilaku dalam kehidupannya.

Hasil olahan deskriptif menunjukkan bahwa indikator dari komitmen kerja yang memiliki skor terendah adalah keterlibatan dalam kegiatan yang berhubungan dengan pekerjaan. Hal tersebut dapat diartikan bahwa ternyata sebagian besar responden dalam melaksanakan pekerjaan kurang suka mencari ide-ide baru dalam pengembangan pembelajaran 
dan jarang untuk diminta memberikan masukan untuk evaluasi kegiatan pembelajaran. Selain itu, untuk indikator keterlibatan dalam kegiatan yang berhubungan dengan pekerjaan masih ditemukan para responden jarang rela bekerja ekstra dengan insentif yang kurang sesuai dan hanya sedikit yang mampu meluangkan waktu untuk bersedia hadir mengerjakan pekerjaan yang dibebankan kepada guru diluar jam mengajar dan masih ditemukannya responden yang malas mengikuti kegiatan pengembangan kirukulum yang diadakan sekolah. jika beberapa hal tersebut dibiarkan tanpa pembenahan yang serius baik dari pribadi para guru maupun pihak dinas dan kepala sekolah, maka responden dalam hal ini guru bidang studi ekonomi akan menjalankan kegiatan pembelajaran tidak optimal dan akan berdampak pada motivasi kerja para guru bidang studi IPS SMAN Kabupaten Padang Pariaman. Hal ini dapat disimpulkan bahwa dengan memperbaiki komitmen kerja guru kearah yang lebih baik maka akan dapat meningkatkan motivasi kerja guru.

Hal lain yang ditemukan untuk indikator ketelibatan dalam melaksanakan kegiatan yang berhubungan dengan pekerjaan adalah para responden yang merasa bangga apa bila dipromosikan sebagai guru inti dan merasa bahagia apabila diberi kesempatan untuk melanjutkan pendidikan formal serta merasa bangga menjadi bagian dari keluarga disekolah dan senang ketika siswa/siswi di sekolah berprestasi. Hal ini sangat mempengaruhi komitmen seseorang dalam bekerja dan dapat meningkatkan motivasi seseorang bekerja dengan lebih baik.

Pernyataan di atas sejalan dengan pendapat Sehartian (2007:44) yang menyatakan komitmen kerja merupakan kecenderungan dalam diri seseorang untuk merasa aktif dengan rasa penuh tanggung jawab. Pendapat Arikunto (2004: 165) komitmen kerja diartikan sebagai kesediaan seseorang untuk terlibat aktif dalam suatu kegiatan dengan tanggung jawab yang tinggi. Dengan adanya komitmen kerja yang baik maka seorang guru cenderung memiliki motivasi kerja yang baik pula dan komitmen mampu mendorong seseorang untuk melaksanakan pekerjaan dengan keteguhan hati dan memiliki pengorbanan dalam bekerja sehingga menimbulkan motivasi dan semangat kerja yang tinggi. Artinya, komitmen seorang guru akan memberikan pengaruh yang berarti terhadap motivasi guru dalam menjalankan tugas mengajarnya.

Berdasarkan uraian di atas, peranan komitmen kerja dan motivasi kerja memiliki pengaruh yang berarti untuk disiplin kerja guru. Untuk mewujudkan disiplin kerja yang baik, maka diperlukan komitmen kerja dan motivasi kerja yang baik pula. Guru yang memiliki disiplin kerja yang tinggi maka ia akan bertanggung jawab dalam melaksanakan tugas yang telah diberikan. Hal ini sejalan dengan Blanchard dalam Rivai (2004:443) menyatakan disiplin berhubungan erat dengan motivasi kerja seseorang, ia mengasumsikan bahwa jika organisasi ingin berhasil maka pimpinan harus membangun motivasi kerja pegawainya, karena dengan terbentuknya motivasi kerja pegawai yang baik maka upaya penegakkan disiplin kerja yang baik akan mudah diusahakan. Sedangkan menurut Tu'u (2004:32) disiplin adalah upaya pengendalian diri dan sikap mental individu atau masyarakat dalam mengembangan kepatuhan dan ketaatan terhadap peraturan dan tata tertib berdasarkan dorongan dan kesadaran yang muncul dalam hatinya. 
Lantham (2004:485) menyatakan bahwa "Work motivation is a set of energietic forces that originate buth within as well as beyond an individual's being, to initiate work realated behaviour and to determine its form. Direction, intensity and duration". Motivasi kerja adalah suatu sikap mental yang dimiliki oleh seseorang yang berasal dari dalam dirinya dan didorong oleh lingkungan yang mendorongnya untuk melakukan suatu kegiatan atau aktifitas untuk mencapai tujuan pribadi dan perusahaan tempat ia bekerja.

Tisnawati dan Saefullah (2005:243) Motivation is the set of forces that cause people to behave in certain ways. Motivasi adalah sesuatu yang mendorong seseorang untuk menunjukkan perilaku tertentu. Hal ini dapat diartikan motivasi kerja berpengaruh terhadap disiplin kerja guru bidang studi IPS SMAN Kabupaten Padang Pariaman.

Dari hasil penelitian dapat disimpulkan bahwa disiplin kerja guru yang didukung oleh komitmen kerja guru yang dijalankan dengan baik dan optimal serta adanya motivasi kerja yang tinggi akan memberikan pengaruh yang berarti terhadap disiplin kerja guru bidang studi IPS SMAN Kabupaten Padang Pariaman. Dengan arti, untuk meningkatkan disiplin kerja yang baik maka diperlukan komitmen dan motivasi kerja yang baik pula.

\section{PENUTUP}

\section{Simpulan}

Berdasarkan hasil penelitian dan pembahasan tentang pengaruh komitmen kerja dan motivasi kerja guru bidang studi IPS SMAN Kabupaten Padang Pariaman, maka dapat ditemukan beberapa kesimpulan sebagai berikut:

1. Komitmen kerja berpengaruh signifikan terhadap motivasi kerja guru bidang studi IPS SMAN
Kabupaten Padang Pariaman. Hal ini mengindikasikan dengan adanya komitmen kerja yang tinggi akan memberikan pengaruh terhadap peningkatan motivasi kerja guru yang lebih tinggi. Dengan demikian peran individu guru bidang studi IPS dalam membangun komitmen kerja dirinya untuk bekerja akan berpengaruh terhadap motivasi kerjanya.

2. Komitmen kerja dan motivasi kerja berpengaruh signifikan terhadap disiplin kerja guru bidang studi IPS SMAN Kabupaten Padang Pariaman. Hal ini mengindikasikan bahwa dengan adanya komitmen kerja dan motivasi kerja yang tinggi yang ditunjukkan oleh guru bidang studi IPS SMAN Kabupaten Padang Pariaman akan dapat meningkatkan disiplin kerja guru dalam melaksanakan tugas dan tanggung jawabnya sebagai seorang guru.

3. Terdapat pengaruh langsung komitmen kerja dan motivasi kerja terhadap disiplin kerja, dimana pengaruh komitmen kerja lebih kecil dibandingkan dengan pengaruh langsung motivasi kerja terhadap disiplin kerja guru bidang studi IPS SMAN Kabupaten Padang Pariaman.

4. Terdapat pengaruh tidak langsung dari komitmen kerja melalui motivasi kerja terhadap disiplin kerja guru bidang studi IPS SMAN Kabupaten Padang Pariaman, dimana motivasi kerja memberikan pengaruh lebih besar terhadap disiplin kerja guru dan ini mengindikasikan bahwa komitmen kerja secara tidak langsung melalui motivasi kerja dapat meningkatkan disiplin kerja guru bidang studi IPS SMAN Kabupaten Padang Pariaman dalam melaksanakan tugas dan tanggung jawabnya sebagai seorang guru.

\section{Saran}


Berdasarkan hasil penelitian maka disarankan:

1. Bagi kepala sekolah SMAN Kabupaten Padang Pariaman diharapkan dapat meningkatkan komitmen kerja guru dengan cara merangsang para guru untuk dapat terlibat aktif dalam penyusunan program, aktif memberikan masukan dalam rapat, memberikan masukan untuk evaluasi kegiatan pembelajaran serta kepala sekolah mampu mempromosikan para guru sebagai guru inti. Hal mengenai motivasi kerja guru di harapkan kepala sekolah SMAN Kabupaten Padang Pariaman diharapkan mampu motivasi kerja guru dengan menjalankan tugas dengan baik serta memberikan kesempatan kepada para guru untuk dapat melanjutkan pendidikan formal, memberikan bonus kepada guru yang menjalankan tugas tambahan, memberikan penilaian yang positif kepada para guru yang memiliki semangat dalam bekerja. Dengan adanya komitmen dan motivasi kerja yang tinggi maka akan mewujudkan disiplin kerja yang tinggi. Disiplin kerja yang tinggi akan mampu mencapai visi, misi dan tujuan sekolah yang telah ditetapkan.

2. Bagi guru bidang studi IPS SMAN Kabupaten Padang Pariaman agar dapat membangun komitmen dan motivasi kerja yang baik dengan cara menjalankan tugas tidak menunggu perintah dari kepala sekolah, mencantumkan materi pengayaan dalam membuat rencana pembelajaran, para guru memiliki target dalam mengajar serta taat terhadap peraturah yang telah ditetapkan sehingga memperolah disiplin kerja yang optimal.

3. Bagi peneliti selanjutnya dapat melakukan penelitian lebih lanjut untuk dapat melihat pengaruh lain yang memberikan pengaruh lain terhadap disiplin kerja guru yang telah peneliti lakukan.

Catatan:

Artikel ini ditulis dari tesis penulis di Pascasarjana Universitas Negeri Padang dengan tim penguji Prof. Dr. H. Agus Irianto, Dr. Sri Ulfa Sentosa MS.

\section{DAFTAR PUSTAKA}

10.22202/economica.2015.v3.i2.257

Arikunto. 2006. Prosedur Penelitian suatu Pendekatan Praktek. Jakarta: Rineka Cipta.

Hamzah, B Uno. 2008. Teori Motivasi \& Pengukurannya. Jakarta: PT. Bumi Aksara.

Hasibuan. 2007. Manajemen Sumberdaya Manusia. Jakarta: Bumi Aksara.

Idris. 2010. Aplikasi Model Analisis Data Kuantitatif dengan Program SPSS. Padang FE UNP.

Irianto, Agus. 2007. Statistik Konsep Dasar dan Aplikasinya. Jakarta: Kencana.

Nawawi. 2005. Manajemen Sumber Daya Manusia. Yogyakarta. Gajah Mada University Press.

Kartono. 2008. Pemimpin dan Kepemimpinan. Jakarta. Grafindo.

Poerwadarminto, W.J. 1976. Kamus Umum Bahasa Indonesia. Jakarta : PN. Balai Pustaka.

Riduwan, 2008. Metode dan Teknik Menyusun Tesis. Bandung: Alfabeta. 2011. Path Analysis (Analisis Jalur). Bandung: Alfabeta.

Rivai,M. 2008. Manajemen Sumberdaya Manusia. Remaja Rosdakarya. Bandung.

Rivai, Veithzal. 2004. Manajemen Sumber Daya Manusia Untuk Perusahaan dari Teori ke Praktek. Jakarta: PT. Raja Grafindo Persada.

Robbins Stephen. 2001. Perilaku Organisasi, Versi bahasa Indonesia, edisi kedelapan. PT. Prenhalindo, Jakarta.

Sahertian. 2007. Kemampuan Dalam Manajemen Suatu Pendekatan 
Perilaku. PT. Raja Grafindo Persada. Jakarta.

Tu'u, Tulus 2004. Peran Disiplin Pada Perilaku dan Prestasi Siswa. Jakarta: PT.Gramedia Widiasarana Indonesia.

Undang-Undang No. 20 Tahun 2003, Tentang: Sistem Pendidikan Nasional.

Wardanti. 2010. “Guru Sebagai Pekerja Profesional: Satu Renungan Tentang Sosok Guru Abad 21". Jurnal Ilmiah. Universitas Terbuka. Diakses tanggal 05/02/2010. 